\title{
Morphological abnormalities of diatom silica walls in relation to heavy metal contamination and artificial growth conditions
}

\author{
Elisa Falasco ${ }^{1,3 *}$, Francesca Bona, ${ }^{1}$ Marco Ginepro ${ }^{2}$, Daša Hlúbiková ${ }^{3}$, Lucien Hoffmann ${ }^{3}$ and Luc Ector ${ }^{3}$ \\ ${ }^{1}$ DBAU, University of Turin, Via Accademia Albertina 13, I-10123 Turin, Italy \\ ${ }^{2}$ Analytical Chemistry Department, University of Turin, Via P. Giuria 5, I-10125 Turin, Italy \\ ${ }^{3}$ Department of Environment and Agro-biotechnologies (EVA), Public Research Center - Gabriel Lippmann, Rue du Brill 41, \\ L-4422 Belvaux, Luxembourg
}

\begin{abstract}
Teratological forms of diatoms are non-adaptive phenotypic abnormalities caused by various environmental stresses. Heavy metal contamination and artificial growth conditions are the best known causes. In fact, the recording of abnormal cells in a diatom population or community can give both a temporal and quantitative indication of heavy metal contamination of water bodies. Moreover, long-term cultures generally present a high percentage of abnormal cells due to the scarcity of nutrients, presence of waste products and osmotic pressure. The aim of this paper is to classify and provide photographic documentation and descriptions of all known teratologies occurring in the most widespread freshwater diatom genera.
\end{abstract}

Keywords: aquatic ecosystem health, diatoms, teratological forms

\section{Introduction}

Morphological variation in diatoms can be both adaptive and non-adaptive in response to environmental conditions. Teratological forms are non-adaptive phenotypic abnormalities usually involving the outline of valves or their striation pattern. Some alterations, such as those involving valve outlines, are mechanically conveyed during reproduction, giving rise to a population with a different morphology from that of the parental line (Hustedt, 1956). Others, such as structure and distribution of striations, seem to be limited to a few generations. For this reason, an abnormal valve outline is more frequent than other teratologies (Granetti, 1968a). Other kinds of aberrancy have been noted, but they are rarer. Many environmental stresses seem to be responsible for teratological cell development and the recording of abnormal cells in a diatom population or community can give both a temporal and quantitative indication of the stress. Indeed, several papers report a significant positive correlation between the abundance of teratological cells and environmental stresses such as low current velocity and flow, drought conditions, light intensity, increase in temperature (Antoine and Benson-Evans, 1986), decrease in water quality (Gómez and Licursi, 2003) or herbicide contamination (Debenest et al., 2008).

Heavy metal contamination and artificial growth conditions are the best known causes of teratological forms. In particular, $\mathrm{Cu}, \mathrm{Cd}$ and $\mathrm{Zn}$ seem to be the most effective trace metals in the production of abnormal cells. Copper led to deformed valve outlines in Fragilaria rumpens, F. tenera,

\footnotetext{
* To whom all correspondence should be addressed.

I 8 +39 0116704520; fax: +39 0116704508;

e-mail: elisa.falasco@unito.it

Received 24 June 2009; accepted in revised form 28 August 2009.
}

Eunotia exigua and Eunotia sp. (Barber and Carter, 1981; Ruggiu et al., 1998), twinned valves in Nitzschia delicatissima (Thomas et al., 1980), $90^{\circ}$ rotation in Asterionella formosa frustules (Cattaneo et al., 2004) and large deformities in A. japonica (Fisher and Frood, 1980; Fisher et al., 1981). In general, no atypical ornamentation pattern was recorded. Cadmium $\left(100 \mu \mathrm{g} \mathrm{Cd} \cdot \ell^{-1}\right)$ led to the development of abnormal valve outlines in Achnanthidium spp., Amphora pediculus, Eolimna minima, Gomphonema parvulum, Mayamaea spp. (including M. agrestis) and Nitzschia palea (Morin et al., 2008b). Interruption of the raphe was noticed in Encyonema minutum, Eolimna minima and Sellaphora seminulum, and abnormal pore shape and pattern in E. minima and G. parvulum. Cadmium contamination also caused unusual colony formation of Tabellaria flocculosa (Adshead-Simonsen et al., 1981). Although no studies have been carried out on $\mathrm{Zn}$ as a single pollutant, great importance has been given to combined $\mathrm{Cd}$ and $\mathrm{Zn}$ contamination; these two heavy metals have been responsible for an abnormal valve profile and striation pattern, doubled central area and distorted raphe canal in several species (McFarland et al., 1997; Nunes et al., 2003; Morin et al., 2008a). In particular, these two heavy metals together induced abnormal valve outlines (wiggly or asymmetric frustules) in Fragilaria gracilis, Cocconeis pediculus and $C$. placentula. An abnormal striation pattern and displaced longitudinal area were characteristic of Ulnaria ulna, while, in the same conditions, Planothidium frequentissimum showed a doubled central area and Nitzschia fonticola presented an atypical raphe canal.

'Teratological growths' in cultures were observed in the $19^{\text {th }}$ century by Miquel (1890-1892), who proved that changes in the chemical composition of the culture medium induced the development of abnormal cells. Later, Locker (1950) recorded teratological cells of Fragilaria capucina (abnormal valve outline), while Cholnoky-Pfannkuche (1971) described abnormal cells of Nitzschia palea. Indeed, 
old culture media enriched by metabolic waste matter could be responsible for the production of teratological forms. Abnormal cells stimulated by intense artificial light also easily undergo vegetative reproduction, thus transmitting alterations through the generations (Granetti, 1968a). Between 1960 and 1978, Granetti (1968a; b; 1975a; b; 1978) fully described teratological cells of Diadesmis gallica, Eolimna minima, Fistulifera pelliculosa and Sellaphora seminulum maintained in artificial growth conditions for several years. These Naviculaceae species showed abnormalities involving the valve outline, orientation centre for the striae, raphe system, central and axial areas, central nodule, pores and spines. Nitzschia denticula was a good example to support the hypothesis that the more complex the valve ornamentation, the more teratologies can be developed (Granetti, 1975a). Besides the above-mentioned abnormal features, Nitzschia can present abnormal dislocation of the raphe canal, anomalous development of the pores and atypical internal septum (disorientated or branched).

In long-term cultures, not only nutrients and waste but also salinity can stimulate the production of teratological forms. Increased osmotic pressure acts as microtubule poison and was observed to cause aberrancy in cells of Anomoeoneis sphaerophora f. costata (Schmid, 1980). Furthermore, Håkansson and Chepurnov (1999) found that, at high salinity concentrations, some specimens of Cyclotella meneghiniana showed multiple striae orientation centres and abnormal striation patterns. Teratologies were also observed in long-term cultures of Achnanthes brevipes, Nitzschia palea and Ulnaria ulna (Estes and Dute, 1994), generally involving the valve outline, raphe system, sternum (branched or dislocated), fibulae arrangements and ornamentation pattern.

The main problem underlying the confusion in the literature is the lack of a morphological classification of teratological forms. In view of the fact that abnormal cells could be used in environmental assessments, the $1^{\text {st }}$ step is to create a classification system to provide a common technical basis (thus far unavailable). The aim of this paper is to fill this gap by providing photographs and specific descriptions encompassing a wide range of teratologies found in a heavy metal-contaminated river and long-term cultures.

\section{Materials and methods}

Samples from the Bormida River (Italy) and long-term artificial cultures were examined under light microscopy. Bormida River is an Apennine river flowing on sedimentary rocks (sandstone, marlstone and sand) of the Tertiary Piedmontese Basin. It has been contaminated by heavy metals and other toxic compounds for more than 100 years, from outflow of the chemical plant of the Associated National Chemical Companies (ACNA) of Cengio (Savona, SV). Five sampling stations located between Cengio and Cortemilia (Cuneo, $\mathrm{CN}$ ) were chosen (B1-B5). B1 (Cengio) was located $0.2 \mathrm{~km}$ downstream of the old outfalls of the ACNA factory. B2 (Gabutti di Camerana, CN), B3 (Monesiglio, CN) and B4 (Monesiglio, $\mathrm{CN}$ ) were located downstream of the ACNA outfalls at a distance of respectively $7 \mathrm{~km}, 12.5 \mathrm{~km}$ and $22.5 \mathrm{~km}$. The last station (B5) was located in Cortemilia (CN), ca. $35 \mathrm{~km}$ from Cengio. To record the maximum number of teratological forms of diatoms, seasonal samplings were carried out between 2003 and 2004 following standard sampling methods (Kelly et al., 1998; AFNOR, 2000). No trace of heavy metals was found in the water column, and for this reason we only refer to heavy metal concentrations in river sediments analysed in 2003 by the local environmental protection agency (ARPA, unpublished data). Due to its highly compromised ecological status, it was not possible to identify control sites on the Bormida River. Therefore, we selected 3 control sites (considered as replicates in the following sections) on the Erro River, a tributary of the Bormida with similar physical characteristics but not polluted by nutrients or heavy metals. Geologically, the Erro Valley is located in the Erro-Tobbio complex, a slice of subcontinental mantel characterised by peridotitic rocks (spinel and plagioclase lherzolites, spinel dunites). Heavy metal concentrations in Erro River sediments were analysed by the Chemistry Department of the University of Turin. To investigate the relationships among heavy metals in sediments, we calculated the toxicity coefficient (ToxC) for each metal, taking into consideration the legislative limits given by Bona et al. (1997). ToxC was calculated as $\operatorname{ToxC}_{j}=\left(\left[\mathrm{HMe}_{\mathrm{j} s}\right] /\left[\mathrm{HMe}_{\mathrm{j} 1}\right]\right)$, where $\left[\mathrm{HMe}_{\mathrm{js}}\right]$ was the concentration of the heavy metal $\mathrm{j}$ in the sediments; $\left[\mathrm{HMe}_{\mathrm{jl}}\right]$ was the limit concentration level proposed as ineffective. For the teratological forms, we calculated the deformation factor of species (DF_sp.) as DF_sp. $=\left(\% \mathrm{~S}_{\mathrm{B}}\right) /\left(\% \mathrm{~S}_{\mathrm{E}}\right)$, where $\left(\% \mathrm{~S}_{\mathrm{B}}\right)$ was the number of species presenting teratological forms in the Bormida River; $\left(\% \mathrm{~S}_{\mathrm{E}}\right)$ was the number of species presenting teratological forms in the Erro River. Moreover, we calculated the deformation factor of the percentage of individuals (DF_in.) as $\left(D F \_i n.\right)=\left(\% \mathrm{Nt}_{\mathrm{jB}}\right) /\left(\% \mathrm{Nt}_{\mathrm{jE}}\right)$, where $\left(\% \mathrm{Nt}_{\mathrm{jB}}\right)$ was the percentage of deformed cells of species $\mathrm{j}$ in the Bormida River, and $\left(\% \mathrm{Nt}_{\mathrm{jE}}\right)$ the percentage of deformed cells of species $\mathrm{j}$ in the Erro River. We also calculated the percentage of teratological frustules for each diatom species, taking into consideration the most frequent species in the whole sample (present in at least 2 sampling seasons), showing at least $2 \%$ of abnormal forms in the samples.

Sixteen monospecific cultures belonging to 12 genera and coming from different European rivers were set up in the Public Research Centre - Gabriel Lippmann, Luxembourg. A list of the cultured species is given in Table 4. From each original sample, $2 \mathrm{~m} \ell$ of diatom suspension were put in a sterile flask and $10 \mathrm{~m} \ell$ of standard culture medium (WC Medium; Guillard and Lorenzen, 1972) were added. After 1 to $4 \mathrm{~d}$ of incubation, we isolated individual cells by means of a micropipette and repeatedly washed them in fresh medium. Cultures were maintained in a growth chamber at $15^{\circ} \mathrm{C}$ constant temperature, with cool white fluorescent lamps providing 400 to $700 \mathrm{~nm}$ light. The measured intensity in the growth chamber was $33.1 \pm 3.4 \mu \mathrm{mol} \cdot \mathrm{s}^{-1} \cdot \mathrm{cm}^{-2}$ with a $16 \mathrm{~h}: 08 \mathrm{~h}$ light:dark cycle (Rimet et al., 2004).

Both natural samples and monospecific cultures were treated with hot hydrogen peroxide (110 vols.) and $\mathrm{HCl}(1 \mathrm{~N})$ to obtain a suspension of clean frustules, which were mounted as permanent slides in Naphrax ${ }^{\circledR}$. Light microscope observations were performed using a Leica DMRX light microscope and a Leitz Wetzlar Ortholux with 100x oil immersion objective. Light microscope photographs were taken with a Leica DC500 camera.

\section{Results}

\section{Teratological types}

Based on a review of published reports on the relationships between environmental stresses and abnormal diatom cells 


\begin{tabular}{|l|l|}
\hline \multicolumn{2}{|c|}{ Summary of all existing teratologies in diatoms, } \\
& \multicolumn{1}{|c|}{ Tased on literature reports } \\
\hline Teratology & Description \\
\hline Type 1 & Deformed valve outline \\
\hline Type 2 & Changes in striation pattern, costae and septae \\
\hline Type $\mathbf{3}$ & $\begin{array}{l}\text { Changes in shape, size and position of the longi- } \\
\text { tudinal and central area }\end{array}$ \\
\hline Type $\mathbf{4}$ & Raphe modifications \\
\hline Type 5 & Raphe canal modifications \\
\hline Type $\mathbf{6}$ & $\begin{array}{l}\text { Unusual arrangement of the cells forming } \\
\text { colonies }\end{array}$ \\
\hline Type $\mathbf{7}$ & Mixed type \\
\hline
\end{tabular}

(Falasco et al., 2009), 7 types of teratological forms could be defined (Table 1).

Type 1: deformed valve outline (loss of symmetry relative to both axes; pentagonal or trilobate shapes; abnormal outline: bent, jagged, incised, kidney-shaped, swollen, twinned, wiggly, showing bulbous protrusions, or 'boomerang'-shaped).

Type 2: changes in striation pattern, costae and septae (multiple orientation centres for the striation; branched striae; loss of transverse costae; arrangement and shape of areolae; loss of the areolae or striae).

In addition to these 2 frequent teratologies, there are 5 types of rarer morphological alterations:

Type 3: changes in the shape and size of the longitudinal and central area (e.g. displaced, doubled, abnormally enlarged, absent).

Type 4: modifications of the raphe (split, sinuate or fragmented, sometimes turned down, double or triple, angular, bifurcate, orientated toward the centre of the valve, completely absent, with portions associated with and occasionally connected to the areolae).

Type 5: modifications of the raphe canal system (distorted, curved and occasionally doubled back or displaced, disordered and stretched out fibulae).

Type 6: unusual arrangement of the cells forming colonies.

Type 7: mixed type in which one valve shows more than one kind of teratology, each independent of the others.

\section{Teratological forms in natural conditions}

Cadmium, copper, lead and zinc concentrations in Bormida River sediments are shown in Table 2. Due to the lack of common agreed limits in Italian legislation for heavy metal concentrations in uncontaminated sediments, we refer to Bona et al. (1997).

All heavy metal ToxCs were significantly correlated with each other. In particular, $\mathrm{Pb}$ was correlated with $\mathrm{Cd}\left(0.638^{* *}\right)$, with $\mathrm{Cu}\left(0.690^{* *}\right)$ and with $\mathrm{Zn}\left(0.947^{* * *}\right)$; $\mathrm{Zn}$ was correlated with $\mathrm{Cd}\left(0.717^{* * *}\right)$ and with $\mathrm{Cu}\left(0.462^{*}\right)$. The percentage of species presenting at least one teratological cell in the community diminished from Sites B1 to B5. In general, the species with the highest number of teratological forms belonged to the genera Navicula and Nitzschia. To investigate the relationships among diatom teratological forms and heavy metals in the sediments, we carried out a Spearman correlation analysis of ToxCs and deformation factors (DF_sp. and DF_in.). We found

\begin{tabular}{|l|c|c|c|c|}
\hline \multicolumn{5}{|c|}{ Table 2 } \\
$\begin{array}{r}\text { Heavy metal concentrations in Erro and Bormida } \\
\text { River sediments. No Observed Effects Levels } \\
\text { (N.O.E.L.) }\end{array}$ \\
\hline & $\begin{array}{c}\text { Cd } \\
\text { (mg/kg DW) }\end{array}$ & $\begin{array}{c}\text { Pb } \\
\text { (mg/kg DW) }\end{array}$ & $\begin{array}{c}\text { Cu } \\
\text { (mg/kg DW) }\end{array}$ & $\begin{array}{c}\text { Zn } \\
\text { (mg/kg DW) })\end{array}$ \\
\hline Erro & $0.08 \pm 0.04$ & $11.97 \pm 2.85$ & $37.99 \pm 4.61$ & $64.12 \pm 4.65$ \\
\hline B1 & 0.16 & 24.75 & 19.80 & 94.00 \\
\hline B2 & 0.17 & 27.00 & 28.00 & 81.00 \\
\hline B3 & 0.28 & 38.00 & 28.00 & 120.00 \\
\hline B4 & 0.17 & 17.00 & 15.00 & 64.00 \\
\hline B5 & 0.00 & 22.00 & 27.00 & 70.00 \\
\hline N.O.E.L. & 0.2 & 23 & 28 & 100 \\
\hline
\end{tabular}

a significant positive correlation between $\mathrm{Cd}$ ToxC and DF_sp. $(0.593 * *)$. Moreover, DF_in. of Mayamaea permitis, Navicula gregaria and Nitzschia dissipata was significantly correlated with Cd ToCs, while DF_in. of Encyonema minutum was correlated with ZnToxCs.

A list of the most frequent diatom taxa and the respective teratological types recorded in the samples from the Bormida River is shown in Table 3. Photographs of the most frequent teratologies recorded in the field are shown in Figs. 1 to 96.

The most frequent type of teratology was deformed valve outline (Type 1). Navicula and Nitzschia had the highest number of cells and species affected by Type 1 . This alteration affected only one valve or the whole frustule, involving different portions of the outline. In general, Type 1 cells showed frustule constrictions on the distal (Figs. 2; 7; 21; 23; 26; 29; $44 ; 49$ to $50 ; 66$ ) and/or central portions (Figs. $8 ; 22 ; 25 ; 30 ; 39$; 41 to 42 ), involving one side of the cell (Figs. 7; 20; 22 to 23; $25-31 ; 42 ; 48-49 ; 59 ; 64$ to 66 ) or two sides of the cell (Figs. 2; $39-41 ; 47 ; 50 ; 57-58 ; 60-62)$. Sometimes this affected one pole (Figs. 17 to $19 ; 24 ; 37 ; 63 ; 68$ ), rarely both of them at the same time (Fig. 6). We usually observed a decreased cell surface (due to the valve outline deformation), while an increase was rarely detected (swollen specimens). These unusual valve outlines led to loss of the typical cell symmetry of the affected species. Stringy species, such as Fragilaria rumpens, assumed bent or wiggly shapes. Sometimes the valve surface maintained its shape, while the alterations occurred on the girdle bands (for example Staurosira venter [Figs. 14 to 16] and Aulacoseira italica). This alteration was mainly visible in girdle view, especially in colonies.

Type 2 involved the ornamentation pattern. In some cases, there was loss of the areolae (Figs. 75; 80; 82). As a consequence, we recorded cells with interrupted ornamentation or atypical and alternated striae lengths (e.g. Caloneis bacillum). At times the striation pattern was abnormal and confused (Figs. 78 to 79 ), and sometimes it seemed that 2 or more centres of orientation had been created. An unusual costae arrangement was typical of the genus Diatoma (Figs. 71 to 73).

Only Cocconeis pseudolineata (Fig. 83), Planothidium frequentissimum, Synedra vaucheriae and Fragilaria capucina var. capitellata showed the Type 3 teratology. In the first species, the pseudoraphe was dislocated and bent. In $P$. frequentissimum, the teratology usually affected the horseshoe thickening on the rapheless valve. In F. capucina var. capitellata, we observed an unusual central area: while in normal cells the central area was asymmetric and located in one part of the hemivalve, in the teratological 


\begin{tabular}{|c|c|c|c|c|c|c|c|}
\hline \multicolumn{8}{|c|}{$\begin{array}{c}\text { Table } 3 \\
\text { List of the most frequent types of teratologies recorded in the field. } \\
\text { Details of the teratological types involved in the mixed type (Type } 7 \text { ) are provided in parentheses. }\end{array}$} \\
\hline Diatom taxa & $\begin{array}{c}\text { Type } \\
1\end{array}$ & \begin{tabular}{|c|} 
Type \\
2 \\
\end{tabular} & $\begin{array}{c}\text { Type } \\
3\end{array}$ & $\begin{array}{c}\text { Type } \\
4 \\
\end{array}$ & $\begin{array}{c}\text { Type } \\
5\end{array}$ & $\begin{array}{c}\text { Type } \\
6\end{array}$ & $\begin{array}{c}\text { Type } \\
7 \\
\end{array}$ \\
\hline Achnanthidium biasolettianum (Grunow) Lange-Bertalot & + & + & & & & & \\
\hline Achnanthidium minutissimum (Kützing) Czarnecki & + & & & & & & \\
\hline Amphora pediculus (Kützing) Grunow & + & & & & & & \\
\hline Asterionella formosa Hassall & + & & & & & & \\
\hline Aulacoseira italica (Ehrenberg) Simonsen & + & & & & & & \\
\hline Caloneis bacillum (Grunow) Cleve & & + & & & & & \\
\hline Cocconeis euglypta Ehrenberg & + & & & & & & \\
\hline Cocconeis pediculus Ehrenberg & + & & & & & & \\
\hline Cocconeis pseudolineata (Geitler) Lange-Bertalot & & + & + & & & & \\
\hline Cyclotella atomus Hustedt & + & & & & & & \\
\hline \multicolumn{8}{|l|}{ Cyclotella meneghiniana Kützing } \\
\hline Cyclotella ocellata Pantocsek & + & & & & & & \\
\hline Cymbella excisa Kützing & + & & & + & & & \\
\hline Diatoma moniliformis Kützing & + & + & & & & & $+(1-2)$ \\
\hline Diatoma vulgaris Bory & & + & & & & & \\
\hline Encyonema caespitosum Kützing & + & & & & & & \\
\hline Encyonema minutum (Hilse) Mann & + & + & & + & & & \\
\hline Encyonema silesiacum (Bleisch in Rabenhorst) Mann & + & + & & & & & \\
\hline Encyonema ventricosum (Kützing) Grunow & + & & & & & & \\
\hline Encyonopsis minuta Krammer et Reichardt in Krammer & + & & & & & & \\
\hline Eolimna minima (Grunow) Lange-Bertalot & + & & & & & & \\
\hline Eolimna subminuscula (Manguin) Moser, Lange-Bertalot et Metzeltin & + & & & & & & \\
\hline Fragilaria capucina var. capitellata (Grunow) Lange-Bertalot & & + & + & & & & \\
\hline Fragilaria pinnata Ehrenberg & + & & & & & & \\
\hline Fragilaria rumpens (Kützing) Carlson & + & & & & & & \\
\hline Gomphonema olivaceum (Hornemann) Kützing & + & & & & & & \\
\hline Gomphonema parvulum (Kützing) Kützing & + & & & & & & \\
\hline Gomphonema tergestinum (Grunow in Van Heurck) Fricke & + & & & & & & \\
\hline Mayamaea permitis (Hustedt) Bruder et Medlin & + & & & & & & \\
\hline Melosira varians Agardh & + & & & & & & \\
\hline Navicula antonii Lange-Bertalot et Rumrich & + & & & & & & \\
\hline Navicula capitatoradiata Germain & + & + & & & & & \\
\hline Navicula cryptotenella Lange-Bertalot & + & & & + & & & \\
\hline Navicula gregaria Donkin & + & & & & & & \\
\hline Navicula lanceolata (Agardh) Kützing & + & & & & & & \\
\hline Navicula pygmaea (Ehrenberg) Pantocsek & + & & & & & & \\
\hline Navicula reichardtiana Lange-Bertalot & + & & & & & & \\
\hline Navicula rostellata Kützing & + & & & & & & \\
\hline Navicula tripunctata Bory & + & & & & & & \\
\hline Navicula veneta Kützing & + & & & & & & \\
\hline Nitzschia acicularis (Kützing) W. Smith & + & & & & & & \\
\hline Nitzschia dissipata (Kützing) Grunow & + & & & & + & & $+(1-5)$ \\
\hline Nitzschia fonticola (Grunow) Grunow & + & + & & & + & & \\
\hline Nitzschia inconspicua Grunow & & & & & + & & \\
\hline Nitzschia intermedia Hantzsch ex Cleve et Grunow & + & & & & & & \\
\hline Nitzschia linearis (Agardh) W. Smith & & & & & & & $+(1-2)$ \\
\hline Nitzschia palea (Kützing) W. Smith & + & & & & & & \\
\hline \multicolumn{8}{|l|}{ Nitzschia paleacea Grunow } \\
\hline Nitzschia pusilla (Kützing) Lange-Bertalot & + & & & & & & \\
\hline Planothidium frequentissimum (Lange-Bertalot) Lange-Bertalot & + & & + & & & & $+(1-3)$ \\
\hline Reimeria sinuata (Gregory) Kociolek et Stoermer & + & + & & & & & \\
\hline $\begin{array}{l}\text { Staurosira venter (Ehrenberg) H. Kobayasi in Mayama, S., Idei, M., } \\
\text { Osada, K. \& T. Nagumo }\end{array}$ & + & + & & & & & \\
\hline Surirella angusta Kützing & + & & & & & & \\
\hline Surirella brebissonii var. kuetzingii Krammer et Lange-Bertalot & + & & & & & & \\
\hline Synedra vaucheriae (Kützing) Kützing & + & + & + & & & & \\
\hline Ulnaria ulna (Nitzsch) Compère & + & + & & & & & \\
\hline
\end{tabular}


Figs 1-70

Type 1 teratology.

Examples of deformed valve outlines recorded in the Bormida River

Italy. Scale bar $=$

$10 \mu \mathrm{m}$. Figs 1-5.

Fragilaria rumpens

(Kützing) Carlson.

Figs 6-11. Synedra

vaucheriae (Kützing)

Kützing. Figs 12-13

Staurosira construens

Ehrenberg. Figs

14-16 Staurosira

venter (Ehrenberg)

Kobayasi. Figs 17-19.

Diatoma moniliformis

Kützing. Figs

20-33. Achnanthidium minutissimum

(Kützing) Czarnecki.

Figs 34-35. Cocconeis

euglypta Ehrenberg.

Fig. 36. Gomphonema

olivaceum

(Hornemann)

Brébisson. Figs

37-38. Gomphonema

parvulum Kützing.

Figs 39-42. Navicula

reichardtiana Lange-

Bertalot. Figs 43-46.

Nitzschia dissipata

(Kützing) Grunow.

Figs 47-50. Eolimna

subminuscula

(Manguin) Moser,

Lange-Bertalot et

Metzeltin. Figs

51-56. Eolimna minima (Grunow) Lange-

Bertalot. Figs 57-62.

Navicula gregaria

Donkin. Figs 63-65.

Reimeria sinuata

(Gregory) Kociolek et

Stoermer. Figs 66-69.

Nitzschia inconspicua

Grunow. Fig. 71

Nitzschia acicularis (Kützing) W. Smith.
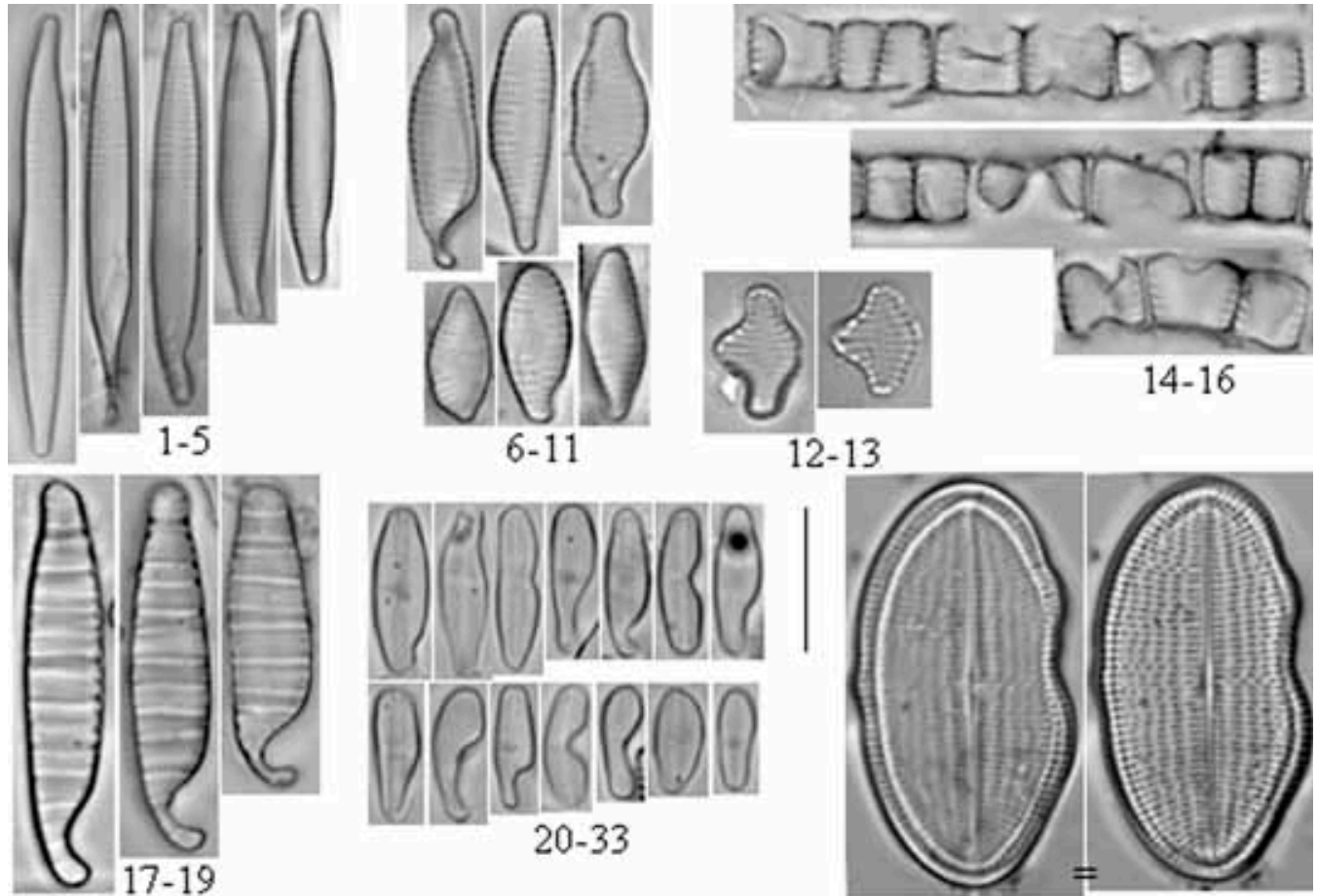

6-11

12-13
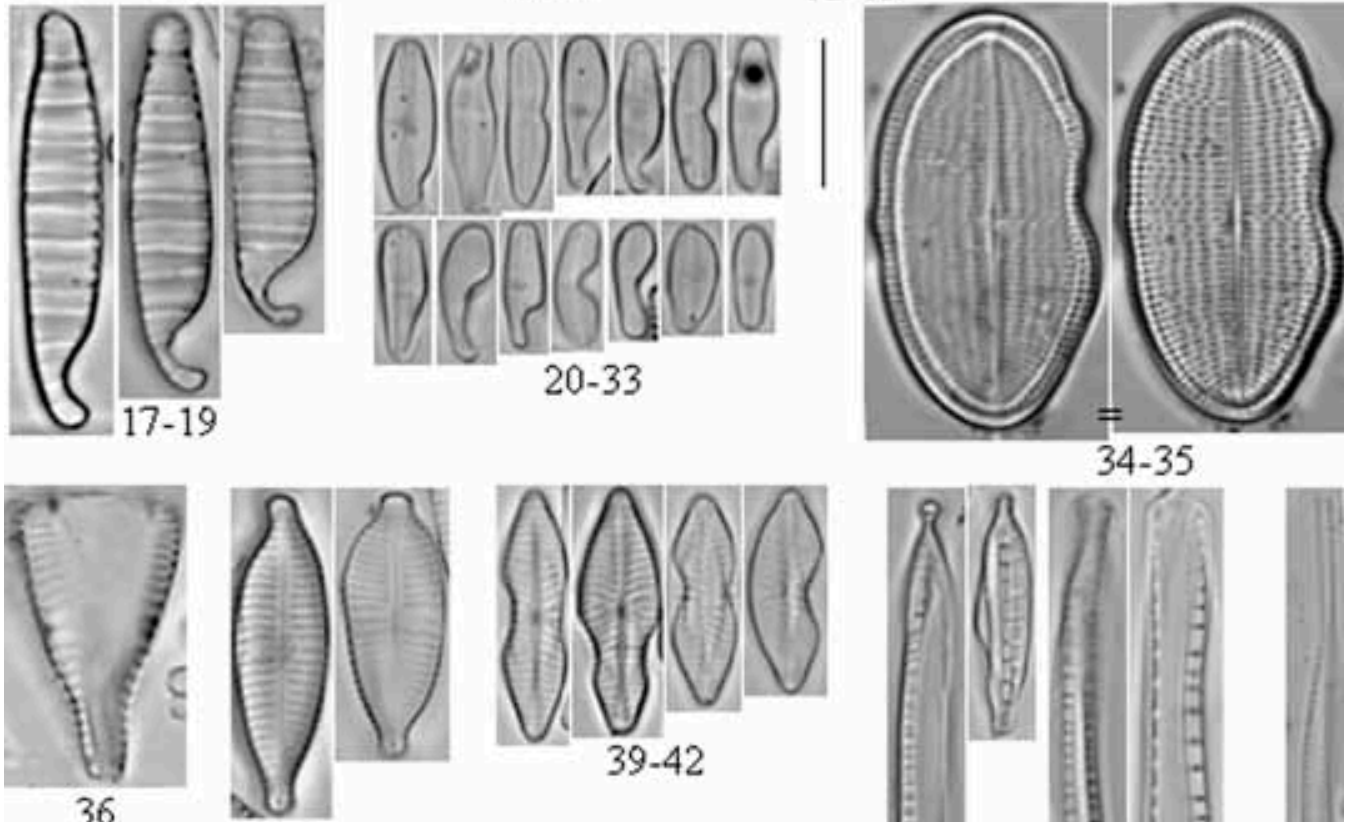

36

$37-38$

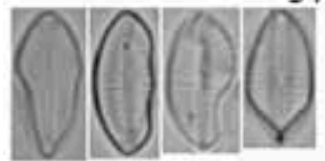

47-50

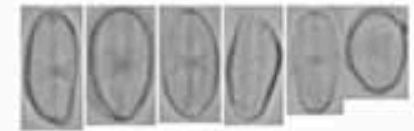

51-56

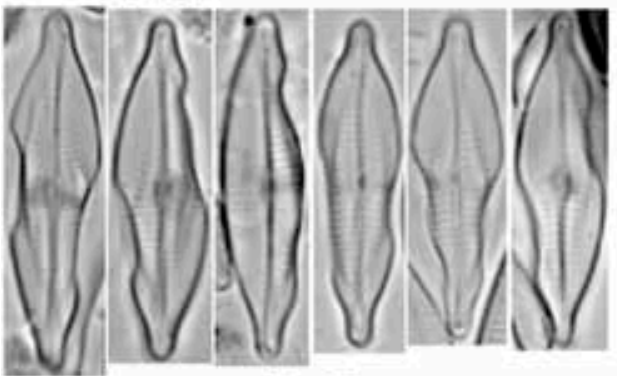

$57-62$

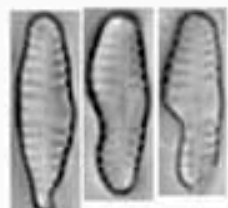

63-65

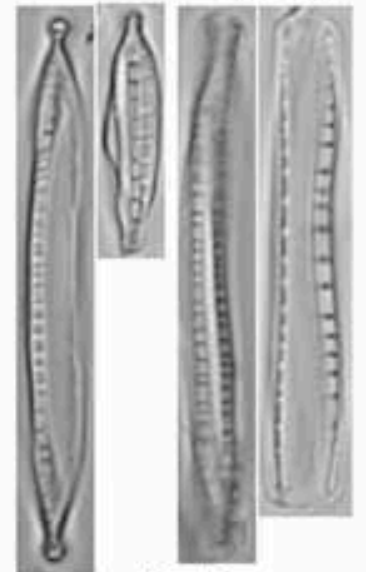

$43-46$

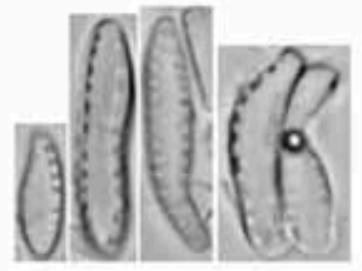

$66-69$ specimen the central area was symmetric, cutting off the pseudoraphe.

Type 4 teratology was characteristic of species of the genera Cymbella and Encyonema. The alterations of the raphe could be observed in $C$. excisa (interrupted raphe slit) and $E$. minutum (dislocation of raphe, Fig. 84). Modifications of the raphe canal were also typical of the genus Nitzschia. Surirella species were only affected by Type 1 teratology, maintaining the usual raphe canal and fibulae arrangement. In Nitzschia dissipata, $N$. fonticola and $N$. inconspicua, the raphe canal sometimes showed abnormal fibulae, both in the shape and pattern. Moreover, it was often displaced or bent. Note that this kind of alteration could be a consequence of an abnormal valve outline, although in this case it was not recorded.

No abnormal arrangement of the cells forming colonies was observed in the samples. As mentioned previously, some unusual colonies were recognised as the consequence of abnormalities in the girdle bands (Figs. 14 to 16).

The mixed type (Type 7) was quite rare and always involved an abnormal valve outline, sometimes linked to an 


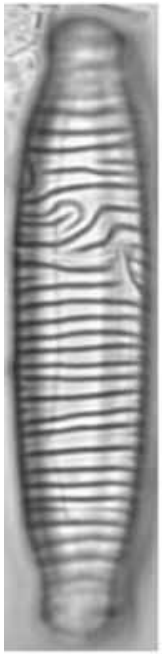

71

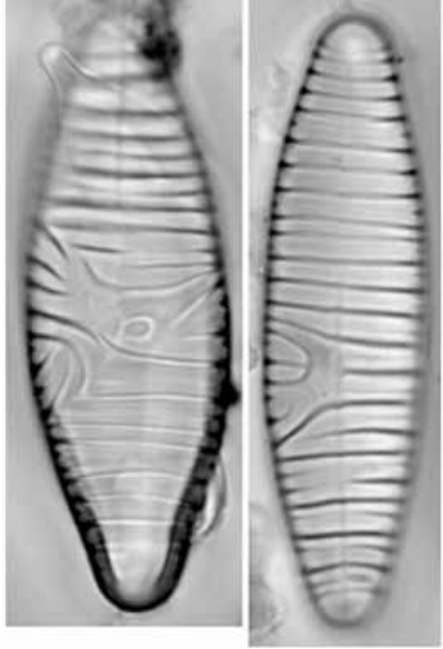

$72-73$

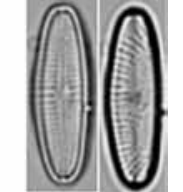

74-75

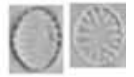

76-77

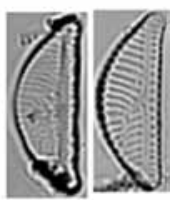

$78-79$

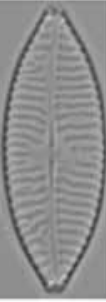

81
Figs 71-82

Type 2 teratology. Examples of deformed ornamentation patterns recorded in the Bormida River, Italy. Scale bar $=10$ $\mu m$. Fig. 71. Diatoma ehrenbergii Kützing. Figs 72-73. Diatoma vulgaris Bory. Figs 74-75. Achnanthidium pyrenaicum (Hustedt) Kobayasi. Figs 76-77. Staurosira venter (Ehrenberg) $H$. Kobayasi in Mayama, S., Idei, M., Osada, K. \& T. Nagum. Figs 78-79. Encyonema minutum (Hilse) Mann. Fig. 80. Encyonema prostratum (Berkeley) Kützing. Fig. 81. Navicula menisculus Schumann. Fig. 82. Navicula lanceolata Ehrenberg.

unusual ornamentation pattern (Figs. 88 to 91; 94 to 95), sometimes to displacement of the central area (Planothidium frequentissimum) or to the raphe canal position (Nitzschia dissipata) or fibulae arrangement (Figs. 92 to 93). Some Araphideae showed an abnormal valve outline, atypical striation pattern and dislocated central area at the same time (Figs. 85 to 86). Loss of the raphe together with an abnormal striation pattern was also observed in Navicula tripunctata (Fig. 96)

\section{Teratological forms in long-term cultures}

The teratological types recorded in long-term cultures are summarised in Table 4. Photographs of the most frequent diatom teratologies recorded are provided in Figs. 97 to 234.

Some culture samples did not show any teratologies at all (Achnanthidium minutissimum) or merely a low percentage (Cyclotella meneghiniana, Diatoma mesodon, Gomphonema coronatum and Reimeria sinuata). Cultures with Cyclotella meneghiniana contained only $10 \%$ of teratological cells (Figs. 97 to 102) and the most frequently recorded abnormalities were abnormal valve outline and atypical orientation of the ornamentations (not directed toward the centre).

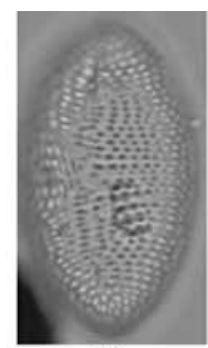

83

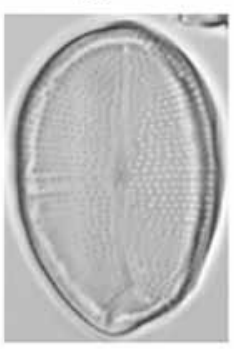

89

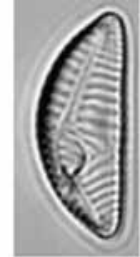

84

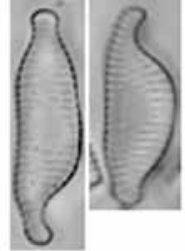

$85-86$

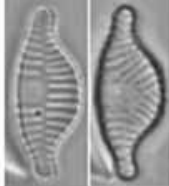

$87-88$

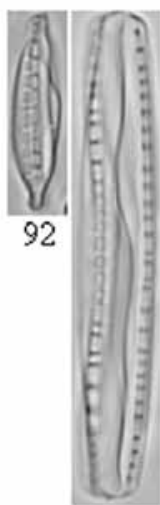

94

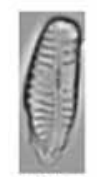

95
96

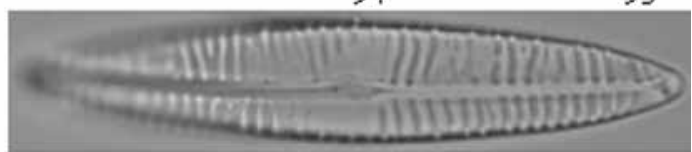

Fig 83

Type 3. Example of a teratology involving the longitudinal area, recorded in the Bormida River, Italy. Scale bar $=10 \mu \mathrm{m}$. Cocconeis pseudolineata (Geitler) Lange-Bertalot.

Fig. 84

Type 4. Example of a teratology involving the raphe system, recorded in the Bormida River, Italy. Scale bar $=10 \mu \mathrm{m}$. Encyonema silesiacum (Bleisch) Mann.

\section{Figs 85-96}

Type 7. Examples of mixed teratologies recorded in the Bormida River, Italy. Scale bar $=10 \mu \mathrm{m}$. Figs 85-86. Fragilaria capucina var. capitellata (Grunow) Lange-Bertalot. Figs 87-88. Synedra vaucheriae (Kützing) Kützing. Fig. 89. Cocconeis sp. Figs 90-91. Encyonema sp. Figs 92-93. Nitzschia dissipata (Kützing) Grunow. Fig. 94. Encyonema silesiacum (Bleisch) Mann. Fig. 95. Reimeria sinuata (Gregory) Kociolek et Stoermer.

Fig. 96. Navicula tripunctata Bory.

The only abnormality in Diatoma mesodon cultures was an atypical costae pattern, affecting $10 \%$ of the population (Figs. 110 to 115). Less than $10 \%$ of Gomphonema coronatum cells (Figs. 233 to 234) showed loss of the areolae, sometimes of the whole stria, and abnormal raphe (doubled, wavy or fragmented); only a few cases of abnormal valve outline were recorded. Teratological cells of Reimeria sinuata (Figs. 224 to 232) usually showed abnormal valve outline, sometimes dislocated central area and abnormal pattern of striation; however, the percentage of abnormal cells was relatively low $(12 \%)$.

High percentages of teratologies were recorded in some culture samples (Cocconeis sp., Cymbella tumida, Encyonema silesiacum, E. lange-bertalotii, Fragilaria rumpens, Gomphonema micropus, G. parvulum, G. rosenstockianum, Mayamaea permitis, Nitzschia linearis, $N$. palea and Ulnaria ulna). Cocconeis sp. (Figs. 141 to 150) showed an abnormal valve outline, atypical pattern of striation and abnormal pseudoraphe (branched or bent). 


\begin{tabular}{|c|c|c|c|c|c|c|c|}
\hline \multicolumn{8}{|c|}{$\begin{array}{c}\text { Table } 4 \\
\text { List of the most frequent types of teratologies recorded in long-term cultures. } \\
\text { Details of the teratological types involved in the mixed type (Type 7) are provided in parentheses. }\end{array}$} \\
\hline Diatom taxa & $\begin{array}{c}\text { Type } \\
1\end{array}$ & $\begin{array}{c}\text { Type } \\
2\end{array}$ & $\begin{array}{c}\text { Type } \\
3\end{array}$ & $\begin{array}{c}\text { Type } \\
4\end{array}$ & $\begin{array}{c}\text { Type } \\
5\end{array}$ & $\begin{array}{c}\text { Type } \\
6\end{array}$ & $\begin{array}{c}\text { Type } \\
7\end{array}$ \\
\hline \multicolumn{8}{|l|}{ Achnanthidium minutissimum (Kützing) Czarnecki } \\
\hline Cocconeis sp. & + & + & + & & & & \\
\hline Cyclotella meneghiniana Kützing & + & + & & & & & \\
\hline Cymbella tumida (Brébisson) Van Heurck & + & + & + & + & & & $+(2-4 ; 1-2-3 ; 1-2)$ \\
\hline Diatoma mesodon Kützing & & + & & & & & \\
\hline Encyonema lange-bertalotii Krammer & + & + & & + & & & \\
\hline Encyonema silesiacum (Bleisch in Rabenhorst) Mann & + & + & & + & & & \\
\hline Fragilaria rumpens Kützing & + & + & + & & & & $+(1-2 ; 1-2-3)$ \\
\hline Gomphonema coronatum Ehrenberg & + & + & & & & & \\
\hline Gomphonema micropus Kützing & & + & & + & & & $+(1-2)$ \\
\hline Gomphonema parvulum (Kützing) Kützing & + & + & & + & & & \\
\hline Gomphonema rosenstockianum Lange-Bertalot et Reichardt & + & & + & + & & & \\
\hline \multicolumn{8}{|l|}{ Mayamaea permitis (Hustedt) Bruder et Medlin } \\
\hline Nitzschia linearis (Agardh) W. Smith & + & & & & + & & \\
\hline Nitzschia palea (Kützing) W. Smith & + & & & & & & \\
\hline Reimeria sinuata (Gregory) Kociolek et Stoermer & + & + & + & & & & \\
\hline Ulnaria ulna (Nitzsch) Compère & + & + & + & & & & $+(1-2)$ \\
\hline
\end{tabular}

The loss of longitudinal area, often reduced to one point, led to an abnormal striation pattern. Cymbella tumida cultures (Figs. 170 to 176) showed a huge percentage of teratological forms (over $98 \%$ ), with a wide range of types. Type 1 abnormalities included loss of transverse or longitudinal symmetry, and the cells were stretched and distorted; Type 2 was represented by loss of the areolae and a confused striation pattern. We also noticed the dislocation or complete loss of the central area, and interruption of the raphe, which sometimes was curved. The mixed type was also observed in Encyonema species: loss of areolae was often coupled with interruption of the raphe, with abnormal valve outline and/or dislocated central area. Abnormal valve outline was recorded together with atypical striation pattern. A very high percentage of teratological forms was observed in Encyonema silesiacum (Figs. 177 to 193) and Encyonema cf. lange-bertalotii (Figs. 194 to 208) cultures (96\% and 99\% respectively). Even though most of the Encyonema cells were small and round, few cells with Type 1 teratology were recorded. The most frequent teratologies presented by the genus Encyonema were Types 2 and 4: the pattern of striation was abnormal, usually induced by an atypical raphe (absent, curved, wiggly or branched). Fragilaria rumpens presented small rounded cells, losing the typical linear shape (Figs. 103 to 109). The atypical valve outline was swollen, incised or bent. The pattern of striation was disordered (Fig. 105) and with loss of areolae (Fig. 109). The central area was sometimes dislocated, especially in small cells. Mixed types consisted of an abnormal valve outline together with an atypical striation pattern (Fig. 105) and sometimes with a dislocated central area as well.

Gomphonema micropus showed a high percentage of teratological cells (50\%) (Figs. 151 to 160). The most frequent abnormalities were abnormal valve outline, often swollen (Figs. 151; 155; 157 to 158), and loss of areolae (Figs. 154 to $158 ; 160)$. An abnormal pattern of striation was often linked to loss of areolae. Less frequent but present were interruption of the raphe slit and loss of one raphe branch; consequently, the striae orientation was directed toward one pole instead of the central nodule.

Gomphonema parvulum (Figs. 161 to 169) and G. rosenstockianum (Figs. 125 to 137) cells were very small and rounded, losing the characteristic heteropolarity. G. rosenstockianum had a higher abnormal cell percentage (83.33\%) than G. parvulum (58.18\%), although both species presented the same types of teratologies. While Type 1 was rare, the most frequent abnormalities regarded the pattern of striation (directed toward one pole) and the raphe slit. In the latter case, we observed bent (Figs. 134; 161; 164 to 165), wiggly and branched raphes (Figs. 131 to $132 ; 136$ to 137 ; $162 ; 166$ to 169$)$ with effects on the striation patterns. Cells presenting a branched raphe showed a divided valvar surface with independent ornamentation. The teratologies observed in Mayamaea permitis (Figs. 116 to 124) were Type 1 and dislocated or branched raphes (Figs. 117; 120 to 121; 123 to 124). All the Nitzschia linearis cells $(100 \%)$ had incised valves, either on one side (Figs. 209 to 212; 214) or on two sides (Figs. 213; 215). Less frequent were an abnormal striation pattern or dislocated raphe canal. $28 \%$ of cultured Nitzschia palea cells (Figs. 216 to 223) presented an abnormal valve outline in the middle part of the valves. We never observed raphe canal dislocation in this species. Finally, almost all the Ulnaria ulna samples presented teratological cells $(99 \%)$, with wiggly, arched or undulate valve outline (Figs. 138 to 140), abnormal striation pattern (Figs. 139 to 140), or both together (mixed type) (Figs. 139 to 140), and sometimes a dislocated longitudinal area.

\section{Discussion and conclusion}

The most important factor causing the development of teratological forms in the Bormida River was Cd contamination. Indeed, we found a significant correlation between the number of species affected by teratologies and the $\mathrm{Cd}$ toxicity coefficient. However, the statistical analysis showed that only a few species were potential indicators of heavy 

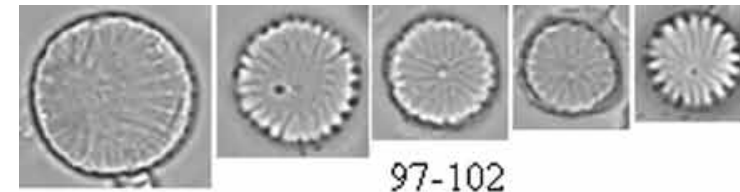

97-102
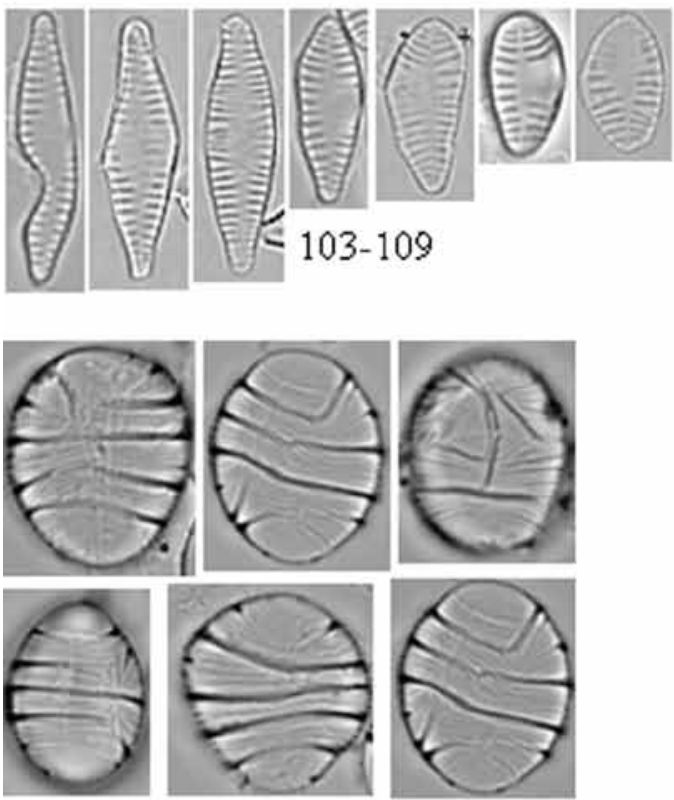

110-115

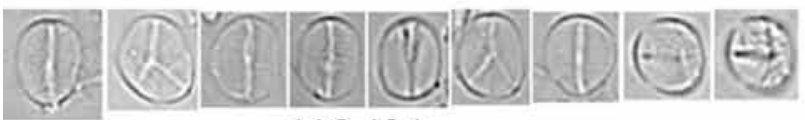

116-124
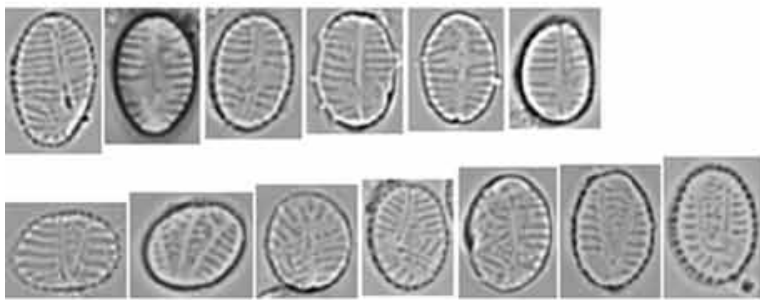

125-137
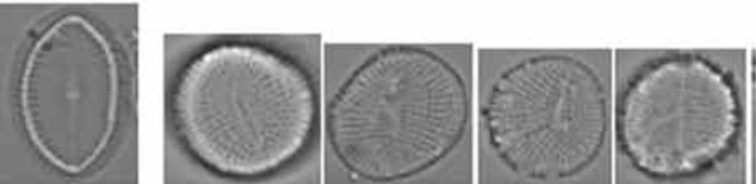

141-150
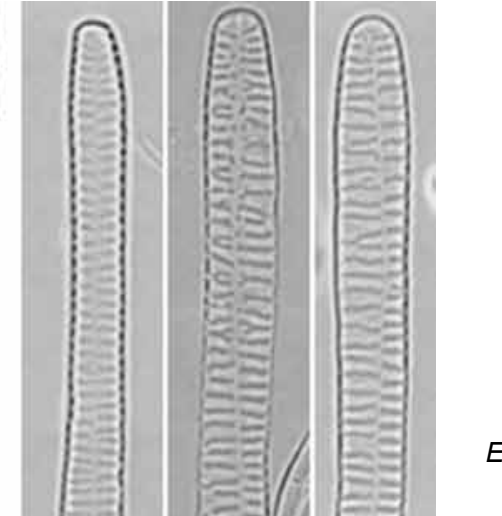

Figs $97-150$

Examples of teratological forms recorded in long-term artificial cultures. Scale bar $=$ $10 \mu \mathrm{m}$. Figs 97-102.

Cyclotella meneghiniana Kützing. Figs 103-109.

Fragilaria rumpens (Kützing) Carlson.

Figs 110-115. Diatoma mesodon (Ehrenberg) Kützing. Figs 116-124.

Mayamaea permitis (Hustedt) Bruder et Medlin. Figs 125-

137. Gomphonema

rosenstockianum Lange-

Bertalot et Reichardt.

Figs 138-140. Ulnaria ulna (Nitzsch) Compère.

Figs 141-150.

Cocconeis $s p$. metal contamination. The percentage of deformed cells of Mayamaea permitis, Navicula gregaria and Nitzschia dissipata was significantly correlated with Cd ToxCs, while the percentage of Encyonema minutum abnormalities was correlated with ZnToxCs. Comparison of our results with those of other authors (Morin et al., 2008b; c) confirmed that some species (such as Cocconeis pediculus, C. placentula, Eolimna minima, Gomphonema parvulum, Nitzschia fonticola, Planothidium frequentissimum, Ulnaria ulna) can develop abnormal forms in relation to Cd pollution, although in our study they were not significantly correlated with the Cd contamination. However, we cannot exclude an additive or synergic effect of heavy metals or the interaction of other environmental factors in the development of teratologies.

The different percentages of teratologies recorded in monospecific cultures depend on the adaptive capacity of each species to grow in artificial conditions. It was recently demonstrated that the natural fluctuation of light intensity and daily variation of temperature are the main factors 


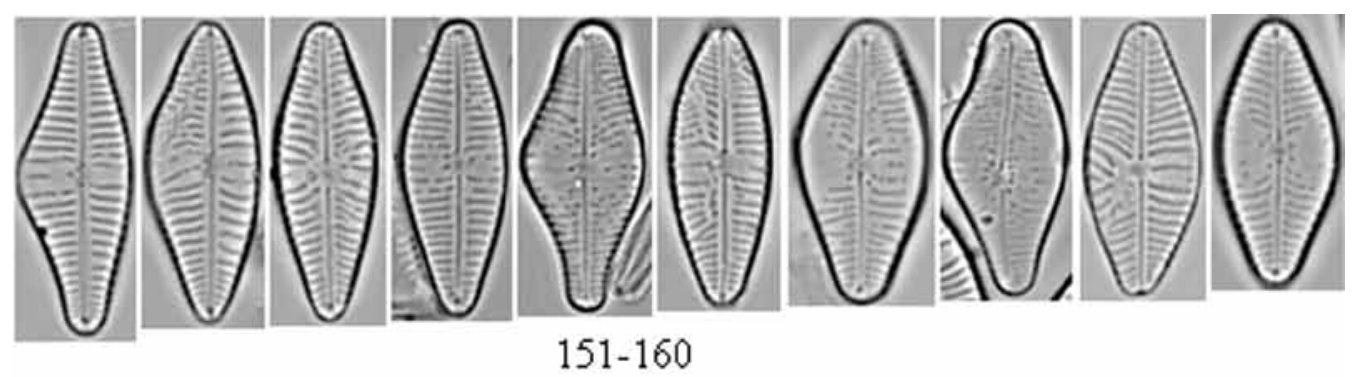

Figs 151-208

Examples of teratological forms recorded in long-term artificial cultures. Scale

bar $=10 \mu \mathrm{m}$.

Figs 151-160.

Gomphonema cf. micropus Kützing. Figs 161-169. Gomphonema parvulum Kützing. Figs

170-176. Cymbella tumida (Brébisson) Van Heurck. Figs 177-193. Encyonema silesiacum (Bleisch) Mann. Figs 194-208. Encyonema cf. lange-bertalotii Krammer.
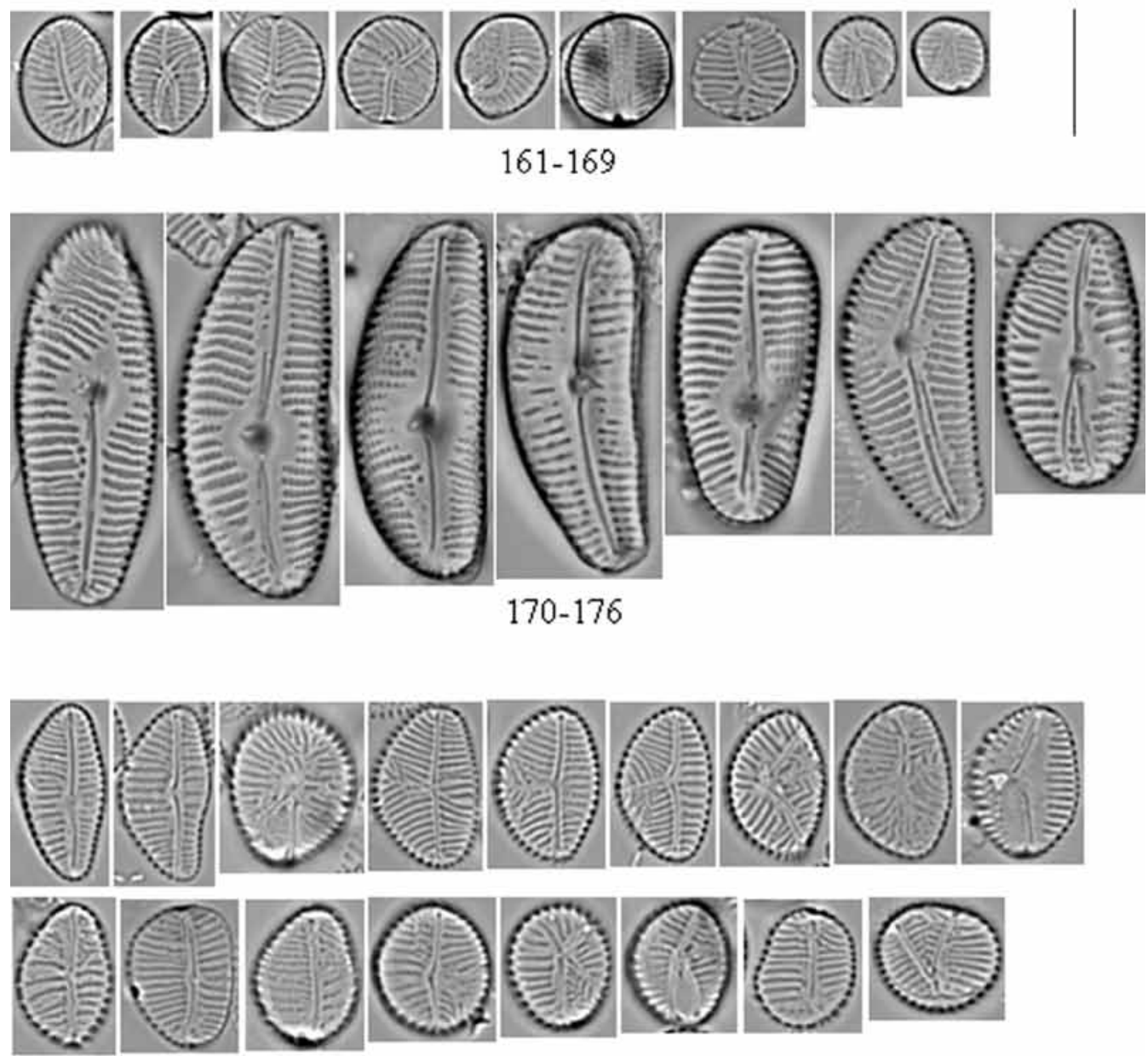

177-193
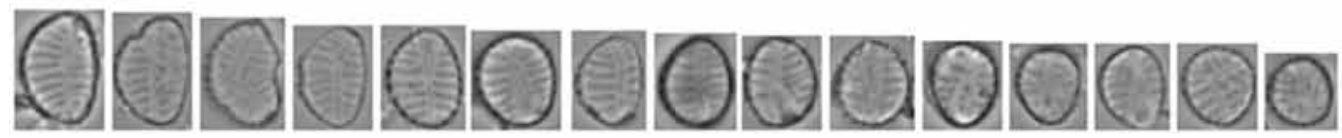

194-208

responsible for higher growth rates of diatoms in natural vs. artificial environments (Morin et al., 2008a). Although artificial growth systems could mimic field conditions, the low flow, oxygenation, nutrient supply and artificial light represent a stress for diatom populations. For these reasons, we hypothesise that competitive, large-late coloniser species (such as Nitzschia linearis or Ulnaria ulna) have a lower tolerance to artificial growth conditions, and the stress they perceive is expressed as teratological forms. Indeed, in our study the competitive taxa showed higher percentages of teratological forms than stress-tolerant or ruderal ones (such as Achnanthidium minutissimum).

The comparison of species growth in natural contaminated and artificial non-contaminated conditions reveals both similarities and differences. Achnanthidium minutissimum is a small adnate species able to survive and reproduce in poorly illuminated habitats (Johnson et al., 1997; Peterson, 1996) and able to colonise a wide range of environments, even those characterised by physical disturbance or mesotrophic conditions. We found that cells of $A$. minutissimum grown in artificial conditions did not present any deformations, while there were abnormal valve 

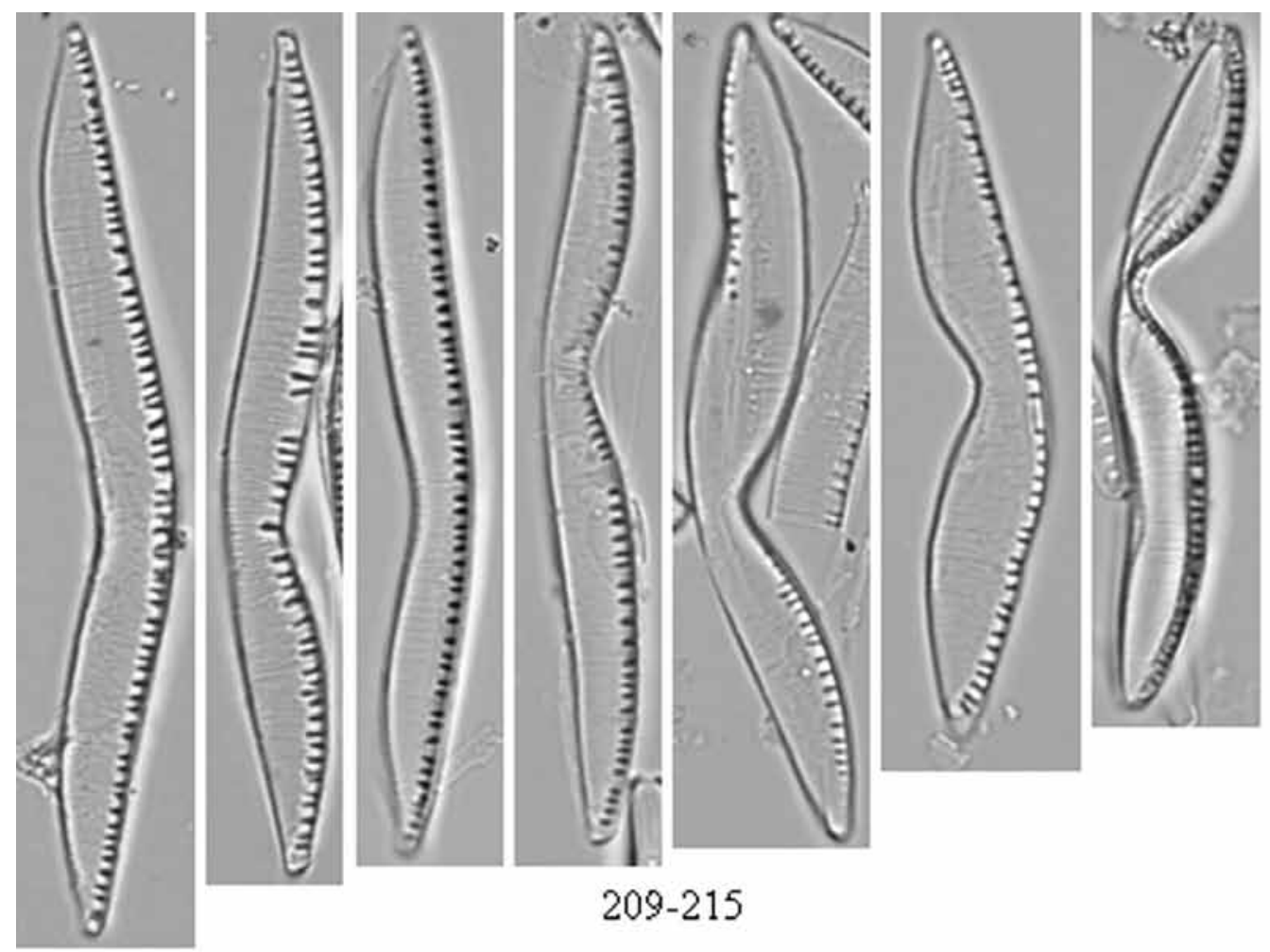

\section{Figs 209-234 \\ Examples of \\ teratological forms recorded in long-term artificial cultures. Scale \\ bar $=10 \mu \mathrm{m}$}

Figs 209-215.

Nitzschia linearis

(Agardh) Smith. Figs

216-223. Nitzschia

palea (Kützing)
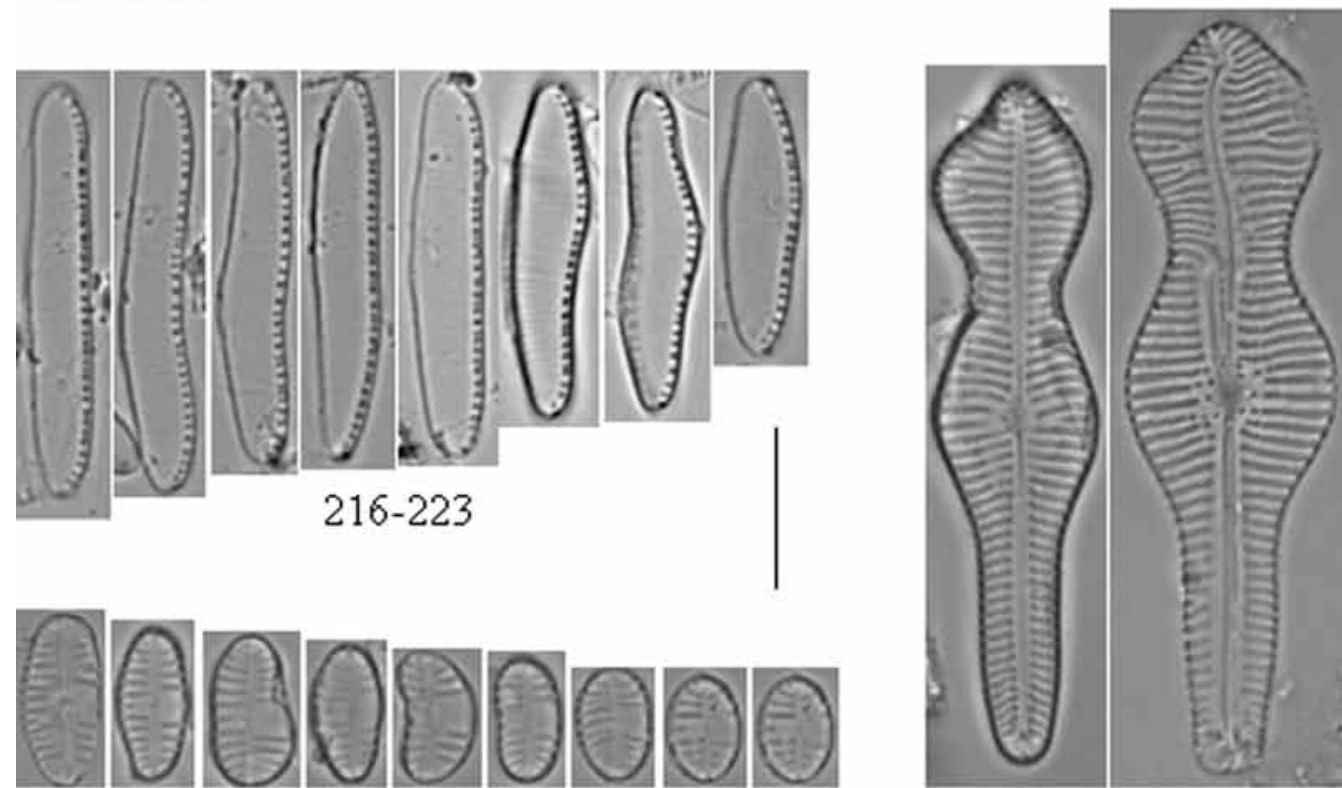

Smith. Figs 224-232.

Reimeria sinuata

(Gregory) Kociolek et

Stoermer. Figs 233.

234. Gomphonema

coronatum Ehrenberg.

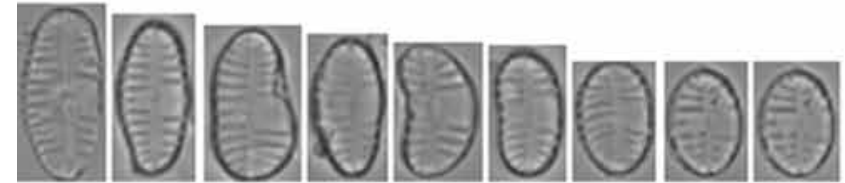

224-232

$233-234$

outlines in natural contaminated samples from the Bormida River. Therefore, A. minutissimum can be considered a useful species for indoor ecotoxicological tests, since it produces teratologies only as a response to specific chemical contaminants.

Fragilaria rumpens from the Bormida River never presented an abnormal striation pattern or longitudinal area, only deformed valve outlines. In contrast, F. rumpens grown in artificial conditions also showed Type 2 and Type 3 teratologies. The same occurred for Gomphonema parvulum, affected by Type 2 and Type 4 teratologies (in addition to Type 1) in long-term cultures. It seems that artificial growth conditions offer greater possibilities for the development of a wider range of teratologies than natural conditions. We could hypothesise that teratologies involving frustule ornamentation should be considered secondary effects with respect to those involving valve outline, and they probably need more time to develop. Moreover, it is possible that abnormalities of the raphe and raphe canal systems prevent correct adhesion of the cells to rock surfaces, disadvantaging specimens affected by these abnormalities. Indeed, these teratologies are rarely recorded in natural environments. On the other hand, cells in artificial conditions are less influenced by flow and can better survive and reproduce even with abnormal anchorage structure. However, we cannot exclude that the teratological type depends on the type of 
stress affecting the species. For this reason, abnormal valve outlines in Fragilaria rumpens could be associated with heavy metal contamination, while physical stress (produced in artificial cultures) leads to an abnormal striation pattern or dislocation of the central area in the same species. Despite this, we noticed a constancy of teratological types in other species: Diatoma mesodon and Encyonema silesiacum usually showed the same teratologies in both natural and artificial conditions.

Although it is not yet possible to establish a direct correlation between a certain environmental stress and a defined morphological alteration, teratological forms of diatoms should be considered a valid tool to provide a first indication of past water contamination (Medley and Clements, 1998; Morin et al., 2007). This paper provides an illustrated classification of the main deviations of frustule morphology in some common diatom freshwater genera, with the aim of stimulating the interest of researchers in this potential stress indicator. However, it is still necessary to investigate the effects of single and multiple contaminants and their additional and synergic effects on diatom communities and monospecific strains in order to consider teratological forms a reliable tool in the assessment of water body contamination.

\section{References}

ADSHEAD-SIMONSEN PC, MURRAY GE and KUSHNER DJ (1981) Morphological changes in the diatom, Tabellaria flocculosa, induced by very low concentrations of cadmium. Bull. Environ. Contam. Toxicol. 26 (1) 745-748.

AFNOR (2000) Norme française NF T90-354: Qualité de l'eau - Détermination de l'Indice Biologique Diatomeés (IBD). Association Française de Normalisation, Paris, 63 pp.

ANTOINE SE and BENSON-EVANS K (1986) Teratological variations in the river Wye diatom flora, Wales, UK. In: Ricard M (ed.) Proc. $8^{\text {th }}$ Int. Diatom Symp. 1984, Koeltz, Koenigstein, Germany. 375-384.

BARBER HG and CARTER JR (1981) Observations on some deformities found in British diatoms. Microsc. 34 (3) 214-226.

BONA F, MAFFIOTTI A and VOLTERRA L (1997) Analisi e recupero dei sedimenti marini. Pitagora Editrice, Bologna, Italy. $139 \mathrm{pp}$.

CATTANEO A, COUILLARD Y, WUNSAM S and COURCELLES M (2004) Diatom taxonomic and morphological changes as indicators of metal pollution and recovery in Lac Dufault (Québec, Canada). J. Paleolimnol. 32 (2) 163-175.

CHOLNOKY-PFANNKUCHE K (1971) Abnormaler Formenwechsel von Nitzschia palea in Kultur. Nova Hedwigia 21 883-886.

DEBENEST T, SILVESTRE J, COSTE M, DELMAS F and PINELLI E (2008) Herbicide effects on freshwater benthic diatoms: induction of nucleus alterations and silica wall abnormalities. Aquat. Toxicol. 88 (1) 88-94.

ESTES A and DUTE RR (1994) Valve abnormalities in diatom clones maintained in long-term culture. Diatom Res. 9 (2) 249-258.

FALASCO E, BONA F, BADINO G, HOFFMANN L and ECTOR L (2009) Morphological variability of diatoms and teratological forms in relation to environmental alterations: a review. Hydrobiologia 623 1-35.

FISHER NS and FROOD D (1980) Heavy metals and marine diatoms: influence of dissolved organic compounds on toxicity and selection for metal tolerance among four species. Mar. Biol. (Berlin) 59 (2) $85-93$.

FISHER NS, JONES GJ and NELSON DM (1981) Effects of copper and zinc on growth, morphology, and metabolism of Asterionella japonica (Cleve). J. Exp. Mar. Biol. Ecol. 51 37-56.

GÓMEZ N and LICURSI M (2003) Abnormal forms in Pinnularia gibba (Bacillariophyceae) in a polluted lowland stream from
Argentina. Nova Hedwigia 77 (3-4) 389-398.

GRANETTI B (1968a) Alcune forme teratologiche comparse in colture di Navicula minima Grun. e Navicula seminulum Grun. Giorn. Bot. Ital. 102 (6) 469-484.

GRANETTI B (1968b) Comportamento di un carattere teratologico comparso in Navicula minima Grun. Giorn. Bot. Ital. 102 (6) 507-513.

GRANETTI B (1975a) Alcune forme teratologiche comparse in colture di Nitzschia denticula Grun. Riv. Idrobiol. 14 (1-2) 97-109.

GRANETTI B (1975b) Alterazioni strutturali in frustuli di Navicula pelliculosa (Bréb.) Hilse coltivata in vitro. Riv. Idrobiol. 14 (1-2) 125-141.

GRANETTI B (1978) Struttura di alcune valve teratologiche di Navicula gallica (W. Smith) Van Heurck. Giorn. Bot. Ital. 112 (1) $1-12$

GUILLARD RRL and LORENZEN CJ (1972) Yellow-green algae with chlorophyllide c. J. Phycol. 8 10-14.

HÅKANSSON H and CHEPURNOV V (1999) A study of variation in valve morphology of the diatom Cyclotella meneghiniana in monoclonal cultures: effect of auxospore formation and different salinity conditions. Diatom Res. 14 (2) 251-272.

HUSTEDT F (1956) Kieselalgen (Diatomeen). Einführung in die Kleinlebwelt. Kosmos Verlag, Stuttgart. 70 pp.

JOHNSON RE, TUCHMAN NC, PETERSON GC (1997) Changes in vertical microdistribution of diatoms within a developing periphyton mat. J. N. Am. Benthol. Soc. 16 (3) 503-519.

KELLY MG, CAZAUBON A, CORING E, DELL'UOMO A, ECTOR L, GOLDSMITH B, GUASCH H, HÜRLIMANN J, JARLMAN A, KAWECKA B, KWANDRANS J, LAUGASTE R, LINDSTRØM EA, LEITAO M, MARVAN P, PADISÁK J, PIPP E, PRYGIEL J, ROTT E, SABATER S, VAN DAM H and VIZINET J (1998) Recommendations for the routine sampling of diatoms for water quality assessments in Europe. J. Appl. Phycol. 10 (2) 215-224.

LOCKER F (1950) Beiträge zur Kenntnis des Formwechsels der Diatomeen an Hand von Kulturversuchen. Österr. Bot. Z. 97 (3-5) 322-332.

McFARLAND BH, HILL BH and WILLINGHAM WT (1997) Abnormal Fragilaria spp. (Bacillariophyceae) in streams impacted by mine drainage. J. Freshwater Ecol. 12 (1) 141-149.

MEDLEY CN and CLEMENTS WH (1998) Responses of diatom communities to heavy metals in streams: the influence of longitudinal variation. Ecol. Appl. 8 (3) 631-644.

MIQUEL P. (1890-1892) De la culture artificielle des diatomées. Le Diatomiste 1 73-75, 93-99, 121-128, 149-156, 165-172.

MORIN S, VIVAS-NOGUES M, DUONG TT, BOUDOU A, COSTE $M$ and DELMAS F (2007) Dynamics of benthic diatom colonization in a cadmium/zinc-polluted river (Riou-Mort, France). Fundam. Appl. Limnol. (Arch. Hydrobiol.) 168 (2) 179-187.

MORIN S, COSTE M and DELMAS F (2008a) A comparison of specific growth rates of periphytic diatoms of varying cell size under laboratory and field conditions. Hydrobiol. 614 (1) 285-297.

MORIN S, COSTE M and HAMILTON PB (2008b) Scanning electron microscopy observations of deformities in small pennate diatoms exposed to high cadmium concentrations. J. Phycol. 44 (6) 1512-1518.

MORIN S, DUONG TT, DABRIN A, COYNEL A, HERLORY O, BAUDRIMONT M, DELMAS F, DURRIEU G, SCHÄFER J, WINTERTON P, BLANC G and COSTE M (2008c) Long-term survey of heavy-metal pollution, biofilm contamination and diatom community structure in the Riou Mort watershed, South-West France. Environ. Pollut. 151 (3) 532-542.

NUNES ML, FERREIRA DA SILVA E and ALMEIDA SFP (2003) Assessment of water quality in the Caima and Mau river basins (Portugal) using geochemical and biological indices. Water, Air, Soil Pollut. 149 (1-4) 227-250.

PETERSON CG (1996) Mechanisms of lotic microalgal colonization following space-cleaning disturbances acting at different spatial scales. Oikos 77 (3) 417-435.

RIMET F, ECTOR L, DOHET A and CAUCHIE HM (2004) Impacts of fluoranthene on diatom assemblages and frustule morphology in indoor microcosms. Vie Milieu 54 (2-3) 145-156. 
RUGGIU D, LUGLIÉ A, CATTANEO A and PANZANI P (1998)

Paleoecological evidence for diatom response to metal pollution in Lake Orta (N. Italy). J. Paleolimnol. 20 (4) 333-345.

SCHMID AMM (1980) Valve morphogenesis in diatoms: A pattern-

related filamentous system in pennates and the effect of APM, colchicine and osmotic pressure. Nova Hedwigia 33 811-847.
THOMAS WH, HOLLIBAUGH JT and SEIBERT DLR (1980) Effects of heavy metals on the morphology of some marine phytoplankton. Phycologia 19 (3) 202-209. 